\title{
Gelatin-Based Edible Coating Combined with Mentha pulegium Essential Oil as Bioactive Packaging for Strawberries
}

\author{
Mohamed Aitboulahsen (D, ${ }^{1}$ Said Zantar, ${ }^{2}$ Amin Laglaoui, ${ }^{3}$ Hicham Chairi, ${ }^{1}$ \\ Abdelhay Arakrak, ${ }^{3}$ Mohammed Bakkali, ${ }^{3}$ and Mounir Hassani Zerrouk ${ }^{1}{ }^{1}$ \\ ${ }^{1}$ Department of Biology, Polydisciplinary Faculty of Larache, Abdelmalek Essaâdi University, B.P. 745 Larache, Morocco \\ ${ }^{2}$ Department of Biology, Faculty of Science and Technology, Abdelmalek Essaâdi University, B.P. 416 Tangier, Morocco \\ ${ }^{3}$ Research Unit of Nuclear Technology, Environment and Quality, National Institute of Agronomic Research, \\ 90010 Tangier, Morocco
}

Correspondence should be addressed to Mounir Hassani Zerrouk; mounirtech@yahoo.es

Received 8 May 2018; Accepted 11 June 2018; Published 4 July 2018

Academic Editor: Francisca Hernández

Copyright (c) 2018 Mohamed Aitboulahsen et al. This is an open access article distributed under the Creative Commons Attribution License, which permits unrestricted use, distribution, and reproduction in any medium, provided the original work is properly cited.

\begin{abstract}
The effect of gelatin-based edible coating incorporated with Mentha pulegium essential oil (MEO) on physicochemical (pH, titratable acidity (TA), weight loss, total soluble solids (TSS), and total phenolic content (TPC)), microbiological (total aerobic mesophilic flora (TAMF) and yeasts and moulds (YM)), and sensorial (color and firmness) characteristics of strawberries stored under refrigeration was studied. Strawberries were coated with gelatin alone (4\%) and/or gelatin combined with two concentrations ( 0.5 and $1 \%)$ of $\mathrm{MEO}$ and stored at $4^{\circ} \mathrm{C}$ for 13 days. Gelatin coating and MEO combination significantly inhibited total flora and moulds and yeasts with comparison to control (uncoated strawberries) and had better hygienic quality at the end of storage. The effect was MEO concentration dependent. Our results also showed that the bioactive coating used in this investigation slowed down changes in $\mathrm{pH}$, TA, weight loss, TSS, firmness, TPC, and color of strawberries. Gelatin coating incorporated with MEO at $1 \%$ protected at least $60 \%$ of strawberries from deterioration after 13 days of storage and could be used as bioactive packaging to prolong the shelf life and an alternative of pesticides use.
\end{abstract}

\section{Introduction}

The Moroccan agricultural sector contributes around $12 \%$ of GDP and remains until today the largest employment provider in the country [1]. Loukkos and Gharb (Northwest of Morocco) are the most important agricultural regions. Red berries occupy the first place of cultivated products providing 169000 tons in 2017 [2].

Strawberries (Fragaria) are perennial plants belonging to the Rosaceae family. They are rich in antioxidants, polyphenols, and other beneficial nutrients [3]. However, strawberries are perishable and maintaining their freshness and quality after harvest is mostly related to the handling, transport, and storage methods that are used [4].

Most of the postharvest fruits and vegetables losses are caused by fungal and bacterial diseases. Botrytis cinerea is a serious problem for strawberry growers. The disease can develop during storage if the fruit has been contaminated during harvesting or handling [5]. Also, Rhizopus soft rot caused by Rhizopus stolonifer can be problematic in small fruits. Cooling and fruit preservation by chemicals like fungicides are traditional techniques that could reduce the incidence of these fungi. However, the problem of resistance development in microbial strains questions their effectiveness especially when the regulation is stricter.

The use of biopolymers-based edible coatings for food preservation has been largely used in the last decades to improve the shelf life of fruits and preserve their freshness [6]. Edible coatings can be defined as a thin layer of edible material that coats the food and limits the migration of water vapor, oxygen, and $\mathrm{CO}_{2}$, among others [7]. Biopolymers usually applied for food preservation can be of different 
natures like protein, lipids, and polysaccharides. The chemical and physical characteristics of the biopolymer used determine their efficacy to be used for food shelf life prolongation. These coatings can also become bioactive by the incorporation of biomolecules with antimicrobial and antioxidant properties.

Essential oils have been largely used to preserve the quality of food due to their antimicrobial and antioxidant activities [8-13]. MEO is considered as one of the most effective essential oils against a large spectrum of bacterial and fungal strains $[14,15]$. Several biopolymers-based coating incorporated with EOs have been used for strawberries preservation $[16,17]$. Due to their mechanical resistance, barrier properties, and sensorial acceptability, gelatin has been largely used to prolong the shelf life of foods such as meat and fish [18-20]. However, to the best of our knowledge, the effect of gelatin coating on strawberry preservation is limited and has been used in only a few studies [21].

In this sense, our work aims at evaluating the combined effect of gelatin-based coating and MEO on physicochemical, microbiological, and sensorial characteristics of strawberries during storage under refrigeration.

\section{Materials and Methods}

2.1. Raw Material. Fresh strawberries (Sabrina) were collected from the experimental center of the National Institute of Agronomic Research (Larache, Morocco) during the season of 2018. They were transported to the laboratory. Noninjured fruit were sorted for their uniformity in size, firmness, and color.

2.2. Essential Oil Isolation. Essential oil used in this investigation was obtained by hydrodistillation from plants of M. pulegium collected in the northeastern part of Morocco (Oujda). The taxonomic identities of the plants were confirmed by comparing voucher specimens with those of known identity previously deposited in the National Herbarium of the Scientific Institute of Rabat.

2.3. Gelatin Coating Formation. Twelve grams of gelatin powder (HiMedia Laboratories Pvt. Ltd, India) was dissolved in $300 \mathrm{~mL}$ of sterile distilled water and stirred at $45^{\circ} \mathrm{C}$ for $10 \mathrm{~min}$. Sorbitol (Loba Chemie Pvt. Ltd, India) (w/w of gelatin) was added to increase mixture stability. 1.5 and $3 \mathrm{~mL}$ of $\mathrm{MEO}$ were added to prepare bioactive gelatin coating at 0.5 and $1 \%$, respectively. TWEEN ${ }^{\circledR} 80$ was used as an emulsifier.

After mixture homogenization, washed strawberries were dipped into the prepared solution for about 90 seconds, they were filtered thereafter using a filter funnel and reset into labeled plastic punnets. Four treatments were prepared:
T1: control (uncoated strawberries)
T2: gelatin coating without $\mathrm{MEO}$
T3: gelatin coating with $0.5 \% \mathrm{MEO}$
T4: gelatin coating with $1 \% \mathrm{MEO}$

The punnets were packed with a plastic wrap and stored in at $4^{\circ} \mathrm{C}$. The physicochemical, microbiological, and sensorial parameters were tested on the first day and after 3, 7, 10 , and 13 days.

2.4. Microbiological Parameters. The count of total aerobic mesophilic flora (TAMF) and yeasts and moulds (YM) were performed according to Jay et al. [22] after $0,3,7$, and 10 days of storage.

2.5. Physicochemical and Sensorial Parameters. $\mathrm{pH}$, total soluble solids (TSS), and titratable acidity (TA) were measured as described in official methods of analysis [23].

The maturity index (MI) was calculated as the ratio of TSS and TA. Fruit firmness was measured using a TA1 texture analyzer (Ametek Lloyd Instruments Ltd, UK), by setting crosshead speed at $1 \mathrm{~mm} / \mathrm{s}$ and penetration depth at $10 \mathrm{~mm}$. Firmness, expressed in $N$, is the textural parameter measured on the resulting force-distance curve.

Fruit color was measured using CR-300 Chroma Meter (Konica Minolta, CR-300, Osaka, Japan), and $L^{*}$ (lightness), $a^{*}$ (redness), and $b^{*}$ (yellowness) values were obtained. The chroma value $C$ was calculated using the following equation:

$$
C=\left(a^{2}+b^{2}\right)^{1 / 2} \text {. }
$$

The difference between the initial and final weight was considered as the total weight loss. Strawberry samples were weighed at the beginning (i.e., 0 days) and at the end of each storage interval. The results were expressed as weight loss percentage. Total phenolic content (TPC) was determined using the Folin-Ciocalteau reagent (Solvachim Laboratoires, Casablanca) according to the method described by Siriwoharn et al. [24] using gallic acid (Loba Chemie Pvt. Ltd, India) as standard. The calibration curve was plotted by mixing $0.5 \mathrm{~mL}$ of $10,50,100,200$, and $400 \mathrm{ppm}$ gallic acid solution with $7.5 \mathrm{~mL}$ of distilled water and $0.5 \mathrm{~mL}$ of the Folin-Ciocalteau reagent. $0.5 \mathrm{~mL}$ of the strawberry sample was added to $7.5 \mathrm{~mL}$ of distilled water and $0.5 \mathrm{~mL}$ of the Folin-Ciocalteau reagent. $0.5 \mathrm{~mL}$ of distilled water was used for blank preparation. Afterwards, all tubes were mixed with a vortex and held for $10 \mathrm{~min}$ at room temperature. Then, $3 \mathrm{~mL}$ of sodium carbonate $(20 \%)$ solution was added to each test tube. Tubes were stirred and placed in a water bath at $40^{\circ} \mathrm{C}$ for $20 \mathrm{~min}$ and then cooled directly in an ice bath for $3 \mathrm{~min}$. The absorbance of all samples was measured using a $755 \mathrm{~nm}$ UV spectrophotometer (JP Selecta S.A., Spain). TPC was expressed in $\mathrm{mg}$ gallic acid equivalent (GAE)/g dry weight.

Visual decay was determined by a visual inspection at 0 , $3,7,10$, and 13 storage days and was estimated as the number of infected fruits divided by the total number of fruits, expressed in percentage (\%).

2.6. Statistical Analysis. All measurements were done in triplicates. Data analyses were performed by one-way analysis of variance (ANOVA) followed by Tukey's post hoc tests to evaluate significant differences among the 


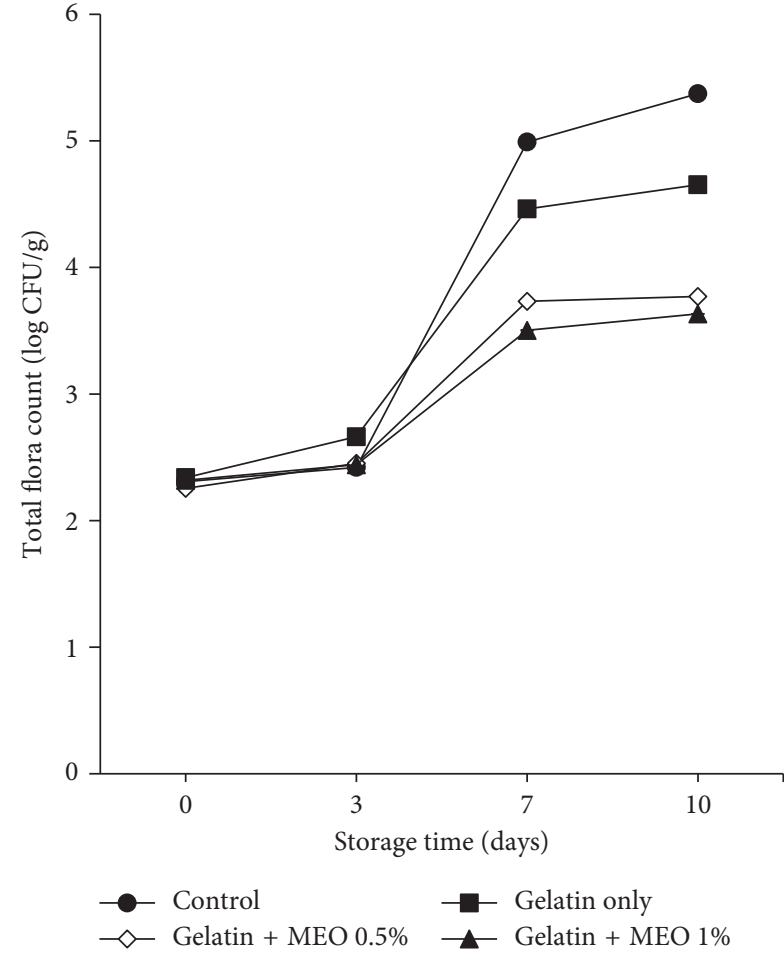

(a)

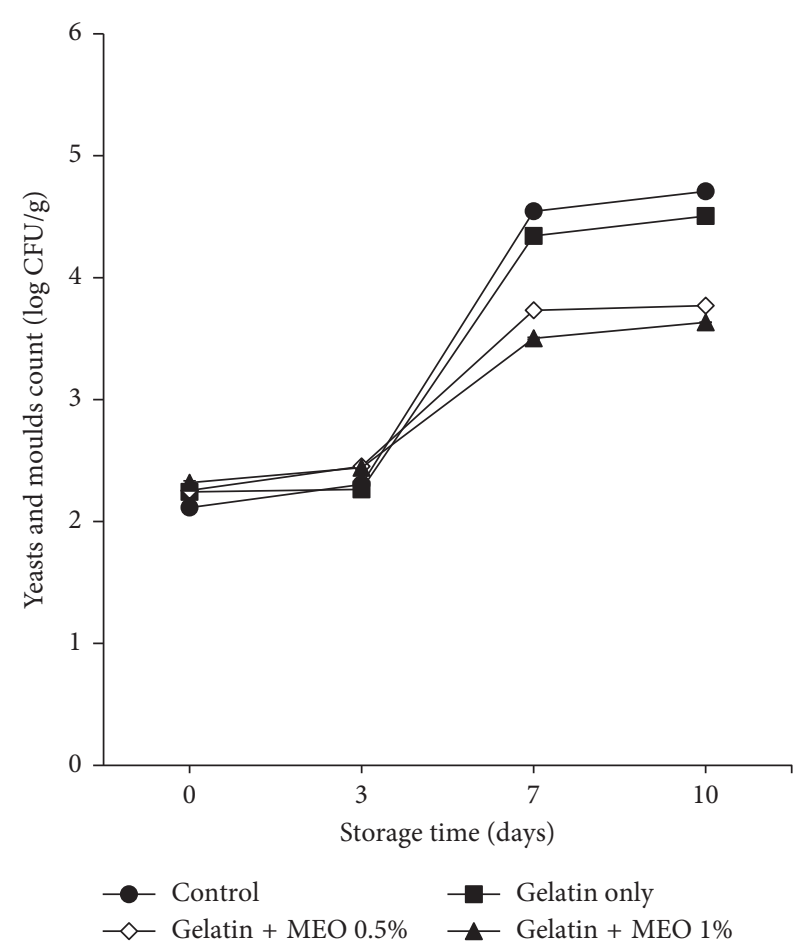

(b)

Figure 1: Total aerobic mesophilic flora (TAMF) (a) and yeast and mould (YM) (b) counts of coated and uncoated strawberries during storage at $4^{\circ} \mathrm{C}$ for 10 days. Vertical bars represent the standard deviation $(n=3)$.

samples at $95 \%$ confidence interval using SPSS computer program, version 20. 0 . The level of significance was $p \leq 0.05$.

\section{Results and Discussion}

3.1. Microbiological Characteristics of Control and Gelatin and/or Gelatin + MEO Coated Strawberries. The effect of gelatin and/or gelatin + MEO coating at two concentrations ( 0.5 and $1 \%$ ) on the evolution of TAMF and YM during storage at $4^{\circ} \mathrm{C}$ is shown in Figures 1 (a) and $1(\mathrm{~b})$.

Initial microbial load of fresh strawberries in this study was $2.3 \mathrm{log} \cdot \mathrm{UFC} / \mathrm{g}$ and $2.2 \mathrm{log} \cdot \mathrm{UFC} / \mathrm{g}$ for TAMF and YM, respectively. Our values are similar to those obtained by Shahbazi [25]. Microbial load was increased significantly $(p \leq 0.05)$ with increasing storage time in all treatments. Gelatin coating alone (T2) retarded slowly $(<0.7 \log \cdot \mathrm{UFC} / \mathrm{g})$ the microbial growth after 10 days of storage. Gelatin coating incorporated with MEO (1\%) (T4) delayed significantly $(p \leq 0.05)$ the microbial growth by $1.74 \log \cdot \mathrm{UFC} / \mathrm{g}$ and $0.82 \mathrm{log}$.UFC/g for TAMF and YM, respectively, after 10 days. At the end of storage, TAMF and YM were in the order of 3.63 and $3.89 \log \mathrm{CFU} / \mathrm{g}$, respectively, for gelatin $+\mathrm{MEO}$ (1\%) (T4) coated strawberries, which is under the limit of acceptance established for the shelf life of fruit-based products [26] and indicate a good hygienic quality of the fruits after 10 days of storage. The inhibition magnitude was EO concentration dependent. This is due to antibacterial and antifungal activities of the MEO largely demonstrated $[15,27]$. Similar behavior was observed by Raquel et al. [28] who found that YM and psychrophils flora decrease following the application of antimicrobial coating. Shahbazi [25] also showed that the use of chitosan coating with Mentha spicata EO was significantly effective against total bacteria, YM, and extend the shelf life of fresh strawberries at least up to 12 days. In our case, the antimicrobial activity of M. pulegium may be attributed to the oxygenated monoterpenes such as pulegone and piperitone generally found in M. pulegium EOs [15].

\subsection{Physicochemical and Sensorial Characteristics of Control and Gelatin and/or Gelatin + MEO Coated Strawberries}

3.2.1. pH, Titratable Acidity (TA), Total Soluble Solids (TSS), and Maturity Index (MI). Variations of $\mathrm{pH}, \mathrm{TA}, \mathrm{TSS}$, and MI during storage at $4^{\circ} \mathrm{C}$ are shown in Table 1 . TA and TSS content decreased while $\mathrm{pH}$ increased significantly $(p \leq 0.05)$ during the storage period for all treatments. Gelatin + MEO (1\%) (T4) coating showed the lowest increase in $\mathrm{pH}$ (3.98) after 13 days, which indicates that the use of this coating slows down changes in $\mathrm{pH}$ values.

Table 1 shows also that gelatin-based coating (T2, T3, and T4) reduced considerably the decrease of TA after 13 days of storage in comparison with the control (T1). Our results are similar to those obtained by Shin et al. and Petriccione et al. [29, 30] who reported that TA decreased with increasing storage period of strawberries. The same authors studying the effect of chitosan coating on strawberries have noticed that TA decrease was more pronounced 
TABLE 1: $\mathrm{pH}$, total soluble solids (TSS), titratable acidity (TA), and maturity index (MI) of coated and uncoated strawberries during storage at $4^{\circ} \mathrm{C}$ for 13 days.

\begin{tabular}{|c|c|c|c|c|c|c|}
\hline Storage time (days) & & 0 & 3 & 7 & 10 & 13 \\
\hline \multirow{4}{*}{$\mathrm{pH}$} & $\mathrm{T} 1$ & $3.80 \pm 0.04^{\mathrm{Aa}}$ & $3.89 \pm 0.02^{\mathrm{Ab}}$ & $3.93 \pm 0.01^{\mathrm{Ab}}$ & $4.19 \pm 0.01^{\mathrm{Ac}}$ & $4.08 \pm 0.02^{\mathrm{Ad}}$ \\
\hline & $\mathrm{T} 2$ & $3.63 \pm 0.03^{\mathrm{Ba}}$ & $3.72 \pm 0.07^{\mathrm{Ba}}$ & $4.09 \pm 0.01^{\mathrm{Bbc}}$ & $4.13 \pm 0.01^{\mathrm{Bb}}$ & $4.01 \pm 0.01^{\mathrm{Bc}}$ \\
\hline & $\mathrm{T} 3$ & $3.76 \pm 0.02^{\mathrm{Aa}}$ & $3.80 \pm 0.15^{\mathrm{ABb}}$ & $3.84 \pm 0.01^{\mathrm{Cb}}$ & $3.97 \pm 0.01^{\mathrm{Cc}}$ & $4.03 \pm 0.02^{\mathrm{Bd}}$ \\
\hline & $\mathrm{T} 4$ & $3.62 \pm 0.02^{\mathrm{Ba}}$ & $3.76 \pm 0.02^{\mathrm{Bb}}$ & $3.79 \pm 0.01^{\mathrm{Db}}$ & $3.88 \pm 0.01^{\mathrm{Dc}}$ & $3.98 \pm 0.01^{\mathrm{Cd}}$ \\
\hline \multirow{4}{*}{ TSS (brix) } & $\mathrm{T} 1$ & $8.53 \pm 0.15^{\mathrm{Aa}}$ & $7.47 \pm 0.25^{\mathrm{Ab}}$ & $6.63 \pm 0.15^{\mathrm{ABc}}$ & $5.17 \pm 0.12^{\mathrm{Ad}}$ & $4.97 \pm 0.12^{\mathrm{Ad}}$ \\
\hline & $\mathrm{T} 2$ & $8.03 \pm 0.15^{\mathrm{ABb}}$ & $6.83 \pm 0.06^{\mathrm{Bb}}$ & $6.80 \pm 0.17^{\mathrm{Ab}}$ & $5.20 \pm 0.10^{\mathrm{Ac}}$ & $5.30 \pm 0.17^{\mathrm{Ac}}$ \\
\hline & $\mathrm{T} 3$ & $8.33 \pm 0.15^{\mathrm{Ba}}$ & $6.43 \pm 0.12^{\mathrm{Cb}}$ & $6.37 \pm 0.06^{\mathrm{Bb}}$ & $5.53 \pm 0.58^{\mathrm{Bc}}$ & $5.07 \pm 0.11^{\mathrm{Ad}}$ \\
\hline & $\mathrm{T} 4$ & $7.96 \pm 0.15^{\mathrm{Ba}}$ & $6.77 \pm 0.06^{\mathrm{BCb}}$ & $6.57 \pm 0.06^{\mathrm{ABbc}}$ & $6.47 \pm 0.12^{\mathrm{Cc}}$ & $6.10 \pm 0.10^{\mathrm{Bd}}$ \\
\hline \multirow{4}{*}{ TA (\%) } & $\mathrm{T} 1$ & $0.57 \pm 0.02^{\mathrm{ABa}}$ & $0.45 \pm 0.01^{\mathrm{Ab}}$ & $0.25 \pm 0.02^{\mathrm{Acd}}$ & $0.22 \pm 0.01^{\mathrm{Ac}}$ & $0.27 \pm 0.01^{\mathrm{Ad}}$ \\
\hline & $\mathrm{T} 2$ & $0.53 \pm 0.01^{\mathrm{Aa}}$ & $0.47 \pm 0.02^{\mathrm{Ab}}$ & $0.31 \pm 0.01^{\mathrm{Bc}}$ & $0.23 \pm 0.01^{\mathrm{Ad}}$ & $0.37 \pm 0.01^{\mathrm{Be}}$ \\
\hline & T3 & $0.58 \pm 0.01^{\mathrm{Ba}}$ & $0.39 \pm 0.03^{\mathrm{Bb}}$ & $0.40 \pm 0.01^{\mathrm{Cb}}$ & $0.34 \pm 0.02^{\mathrm{Bc}}$ & $0.31 \pm 0.01^{\mathrm{Cc}}$ \\
\hline & $\mathrm{T} 4$ & $0.56 \pm 0.01^{\mathrm{ABa}}$ & $0.49 \pm 0.01^{\mathrm{Ab}}$ & $0.47 \pm 0.01^{\mathrm{Dbc}}$ & $0.44 \pm 0.01^{\mathrm{Cc}}$ & $0.37 \pm 0.02^{\mathrm{Bd}}$ \\
\hline \multirow{4}{*}{ Maturity index (\%) } & $\mathrm{T} 1$ & $14.93 \pm 0.29^{\mathrm{Aa}}$ & $16.51 \pm 0.22^{\mathrm{Aad}}$ & $26.93 \pm 2.48^{\mathrm{Ab}}$ & $23.29 \pm 0.25^{\mathrm{Ac}}$ & $18.49 \pm 0.56^{\mathrm{Ac}}$ \\
\hline & $\mathrm{T} 2$ & $15.07 \pm 0.54^{\mathrm{Aa}}$ & $14.45 \pm 0.82^{\mathrm{ABa}}$ & $21.83 \pm 0.54^{\mathrm{Bb}}$ & $24.48 \pm 0.72^{\mathrm{Ac}}$ & $14.29 \pm 0.92^{\mathrm{Ba}}$ \\
\hline & $\mathrm{T} 3$ & $14.26 \pm 0.48^{\mathrm{Aa}}$ & $16.46 \pm 1.47^{\mathrm{Aa}}$ & $15.87 \pm 0.25^{\mathrm{Ca}}$ & $18.98 \pm 0.89^{\mathrm{Bb}}$ & $16.28 \pm 0.65^{\mathrm{Ba}}$ \\
\hline & $\mathrm{T} 4$ & $14.26 \pm 0.63^{\mathrm{Aa}}$ & $13.56 \pm 0.37^{\mathrm{Ba}}$ & $13.99 \pm 0.38^{\mathrm{Ca}}$ & $11.83 \pm 0.11^{\mathrm{Cb}}$ & $16.28 \pm 0.97^{\mathrm{Bc}}$ \\
\hline
\end{tabular}

The values are given as mean \pm standard deviation $(n=3)$. Different capital letters within a column indicate significant differences among treatments $(p \leq 0.05)$. Different small letters within a row indicate significant differences due to storage time $(p \leq 0.05)$. T1: control; T2: gelatin coating only; T3: gelatin + MEO $(0.5 \%)$ coating; T4: gelatin + MEO (1\%) coating.

in uncoated samples (control). Previous studies have suggested that the higher acidity loss in uncoated fruits is due to the use of organic acids as substrates for respiratory metabolism during storage [31]. In this sense, Gol et al. [16] reported that coatings can slow down respiration rate and may therefore reduce the use of organic acids which leads to the retention of TA in coated fruits.

The decrease of TSS content in gelatin + MEO (1\%) coating (T4) was delayed significantly $(p \leq 0.05)$ in comparison to the control (T1) at the end of storage (day 13). Our results agree with those obtained by Amal et al. [32] who reported that incorporation of thymol EO in soy protein or gluten films was the most effective treatments in maintaining TSS during storage and concluded that the application of coatings on the surface of the strawberry reduced respiration rate, hence reducing the loss of TSS. Finally, MI calculated as TSS/TA ratio, the most important parameter for evaluating strawberries quality, shows that uncoated strawberries (T1) exhibited a significant bigger increase $(p \leq 0.05)$ with comparison to the coated ones (T2, T3, and T4), reflecting reduced ripening compared to uncoated strawberries.

3.2.2. Weight Loss and Total Phenolic Content. Figures 2 and 3 show the effect of gelatin and/or gelatin + MEO coating at 0.5 and $1 \%$ on the weight loss and TPC of strawberries during the storage at $4^{\circ} \mathrm{C}$, respectively.

Weight loss increased throughout the storage period for the control (T1) and gelatin coated (T2, T3, and T4) strawberries with significant differences $(p \leq 0.05)$. Uncoated fruits (T1) had the highest weight loss (24\%) after 13 days while gelatin + MEO (1\%) (T4) had the lowest percentage of weight loss (3\%) being under the limit for strawberries acceptance (6\%) (Figure 2). Gelatin alone (T2) also reduces weight loss but not as effective as gelatin + MEO (1\%) (T4) treatment. Our results are in accordance with

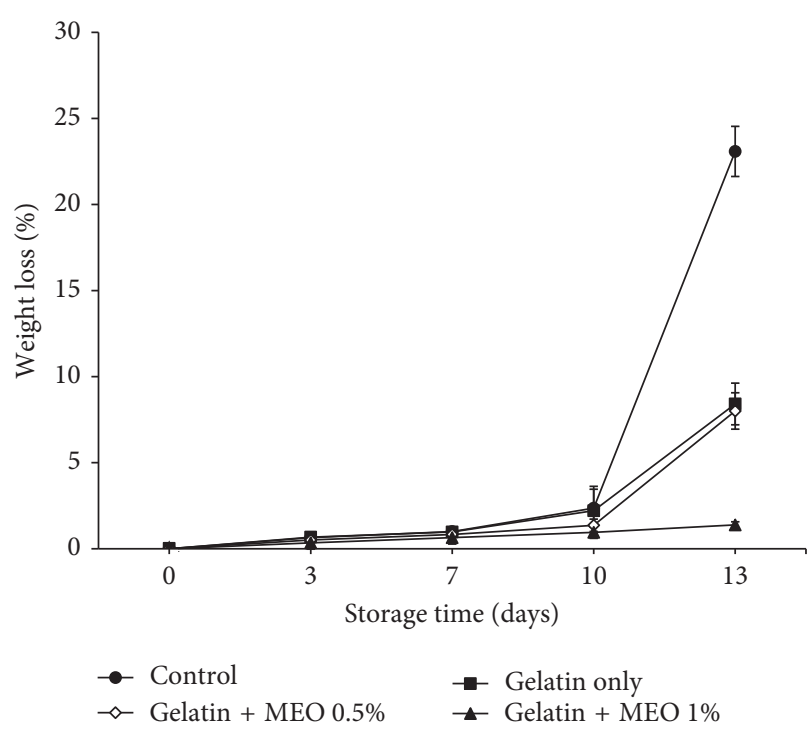

Figure 2: Weight loss of coated and uncoated strawberries during storage at $4^{\circ} \mathrm{C}$ for 13 days. Vertical bars represent the standard deviation $(n=3)$.

Wang et al. [33] demonstrating that coatings reduce respiration rate and water loss. Fakhouri et al. and Poverenov et al. $[21,34]$ report that among the substances used to coat and prolong the shelf life of fruits, gelatin is a feasible alternative to avoid the product's weight loss after harvest. The evolution of TPC in all treatments is summarized in Figure 3.

Total phenolic content (TPC) obtained in this study are in the range of those obtained by Hoda et al. [35] but superior of $\mathrm{Li}$ et al. [36] $(80 \mathrm{mg} / 100 \mathrm{~g})$. Anttonen et al. [37] reported that TPC varies according to many parameters such as variety, level of fertilization, or date of planting. Figure 3 shows also that TPC tends to decrease through the storage 


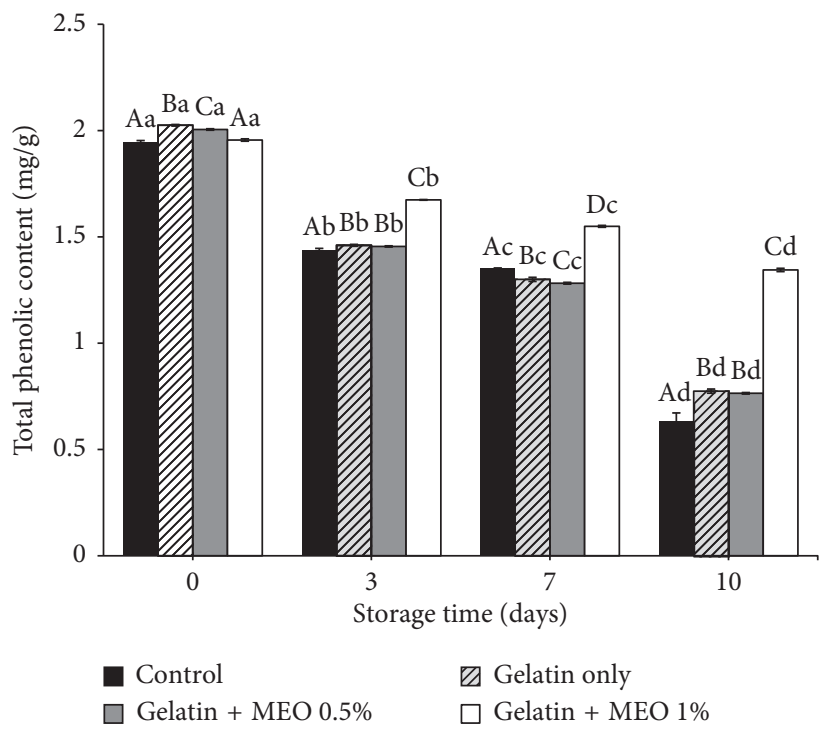

Figure 3: Total phenolic content (TPC) of coated and uncoated strawberries during storage at $4^{\circ} \mathrm{C}$ for 10 days. Vertical bars represent the standard deviation $(n=3)$. Bars with different small letters indicate significant differences due to storage time $(p \leq 0.05)$.

TABLe 2: Firmness and color of coated and uncoated strawberries during storage at $4^{\circ} \mathrm{C}$ for 13 days.

\begin{tabular}{|c|c|c|c|c|c|c|}
\hline \multicolumn{2}{|c|}{ Storage time (days) } & 0 & 3 & 7 & 10 & 13 \\
\hline \multirow{4}{*}{ Firmness $(N)$} & $\mathrm{T} 1$ & $2.14 \pm 0.56^{\mathrm{Aab}}$ & $3.07 \pm 0.62^{\mathrm{Aa}}$ & $3.05 \pm 0.25^{\mathrm{Aa}}$ & $2.52 \pm 0.23^{\mathrm{Aab}}$ & $1.29 \pm 0.86^{\mathrm{Ab}}$ \\
\hline & $\mathrm{T} 2$ & $2.87 \pm 0.81^{\mathrm{Aab}}$ & $3.87 \pm 0.99^{\mathrm{Aab}}$ & $4.86 \pm 0.57^{\mathrm{Aa}}$ & $3.60 \pm 0.25^{\mathrm{Bab}}$ & $2.16 \pm 1.57^{\mathrm{Ab}}$ \\
\hline & $\mathrm{T} 3$ & $2.93 \pm 0.92^{\mathrm{Aa}}$ & $4.01 \pm 1.38^{\mathrm{Aa}}$ & $4.65 \pm 2.07^{\mathrm{Aa}}$ & $4.77 \pm 0.27^{\mathrm{Ca}}$ & $2.95 \pm 1.17^{\mathrm{Aa}}$ \\
\hline & $\mathrm{T} 4$ & $2.24 \pm 0.23^{\mathrm{Aa}}$ & $3.01 \pm 0.40^{\mathrm{Aa}}$ & $3.41 \pm 1.13^{\mathrm{Aa}}$ & $2.77 \pm 0.62^{\mathrm{ABa}}$ & $2.91 \pm 0.92^{\mathrm{Aa}}$ \\
\hline \multirow{4}{*}{$L^{*}$ value } & $\mathrm{T} 1$ & $46.16 \pm 0.92^{\mathrm{Aa}}$ & $42.13 \pm 2.25^{\mathrm{Aab}}$ & $43.68 \pm 1.78^{\mathrm{Aab}}$ & $40.93 \pm 2.58^{\mathrm{Abc}}$ & $37.11 \pm 0.99^{\mathrm{Ac}}$ \\
\hline & $\mathrm{T} 2$ & $44.04 \pm 0.61^{\mathrm{Aa}}$ & $42.06 \pm 1.66^{\mathrm{Aab}}$ & $42.37 \pm 1.60^{\mathrm{Aab}}$ & $41.39 \pm 3.01^{\text {Aab }}$ & $38.77 \pm 1.88^{\mathrm{ABb}}$ \\
\hline & $\mathrm{T} 3$ & $45.98 \pm 0.59^{\mathrm{Aa}}$ & $42.50 \pm 1.44^{\mathrm{Aab}}$ & $42.42 \pm 2.08^{\mathrm{Aab}}$ & $42.90 \pm 0.51^{\mathrm{Aab}}$ & $40.06 \pm 1.79^{\mathrm{ABb}}$ \\
\hline & $\mathrm{T} 4$ & $39.04 \pm 1.03^{\mathrm{Ba}}$ & $46.33 \pm 1.63^{\mathrm{Ab}}$ & $40.15 \pm \pm 0.79^{\mathrm{Aa}}$ & $40.93 \pm 2.58^{\mathrm{Aa}}$ & $41.39 \pm 1.48^{\mathrm{Ba}}$ \\
\hline \multirow{4}{*}{ Chroma value } & $\mathrm{T} 1$ & $30.31 \pm 8.37^{\mathrm{Aa}}$ & $24.22 \pm 1.87^{\mathrm{Aab}}$ & $21.36 \pm 2.10^{\mathrm{Aab}}$ & $19.47 \pm 1.11^{\mathrm{Aab}}$ & $17.56 \pm 3.52^{\mathrm{Ab}}$ \\
\hline & $\mathrm{T} 2$ & $24.69 \pm 0.33^{\mathrm{Aa}}$ & $20.09 \pm 2.25^{\mathrm{Aab}}$ & $16.98 \pm 1.65^{\mathrm{Ab}}$ & $17.66 \pm 2.09^{\mathrm{Ab}}$ & $21.19 \pm 1.72^{\mathrm{Aab}}$ \\
\hline & T3 & $23.77 \pm 2.78^{\mathrm{Aa}}$ & $18.88 \pm 2.24^{\mathrm{Aa}}$ & $19.46 \pm 1.65^{\mathrm{Aa}}$ & $18.26 \pm 1.14^{\mathrm{Aa}}$ & $20.09 \pm 3.95^{\mathrm{Aa}}$ \\
\hline & $\mathrm{T} 4$ & $31.77 \pm 4.62^{\mathrm{Aa}}$ & $22.31 \pm 2.89^{\mathrm{Ab}}$ & $19.43 \pm 2.20^{\mathrm{Ab}}$ & $17.19 \pm 0.74^{\mathrm{Ab}}$ & $20.93 \pm 2.61^{\mathrm{Ab}}$ \\
\hline
\end{tabular}

The values are given as mean \pm standard deviation $(n=3)$. Different capital letters within a column indicate significant differences among treatments $(p \leq 0.05)$. Different small letters within a row indicate significant differences due to storage time $(p \leq 0.05)$. T1: control; T2: gelatin coating only; T3: gelatin + MEO (0.5\%) coating; T4: gelatin + MEO (1\%) coating; $L^{*}$, lightness.

period also in coated (T2, T3, and T4) and uncoated (T1) strawberries. The decrease in TPC through storage could be attributed to the degradation of anthocyanins during the senescence period [38]. Gelatin coating alone (T2) slightly reduces TPC loss. Li et al. [36], using starch-based coating for strawberries preservation, noted that coating reduces the losses of TPC. The same result was obtained by Gol et al. [16] using chitosan-based coating. Surprisingly, gelatin + MEO (1\%) (T4) coating was the most effective treatment that limits losses in TPC after 10 days of storage. In a similar trend, Oms-Oliu et al. [39] concluded that coating treatment with chitosan, starch, and cinnamon EO promotes enzymatic activity of phenylalanine ammonia lyase responsible for the accumulation of total phenols in strawberries.

3.2.3. Firmness, Color, and Decay Rate. Firmness is one of the most important quality parameter for strawberries acceptance. In our study, gelatin-based coatings did not affect significantly firmness of the strawberry fruit during cold storage, and the firmness of the fruits was maintained (Table 2). Our results agree with those obtained by Poverenov et al. [34] for red bell peppers using chitosan/gelatin coating. Amal et al. [32] and Petriccione et al. [30] also showed that strawberries lose their firmness during the storage due to cell walls degradation during storage. The same authors pointed out the positive effect of coating to limit firmness loss. The color parameter is usually used to evaluate the quality and ripening degree of fruits. The results obtained in this study are shown in Table 2, and color changes were estimated by $L$ and chroma values.

Despite that all treatments (from T1 to T4) show significant decrease in the estimated values, gelatin coating clearly slows down these changes. Similar trends were reported by Petriccione et al. [30] and Hernández-Muñoz et al. [40]. Velickova et al. [41] reported that coatings protect 


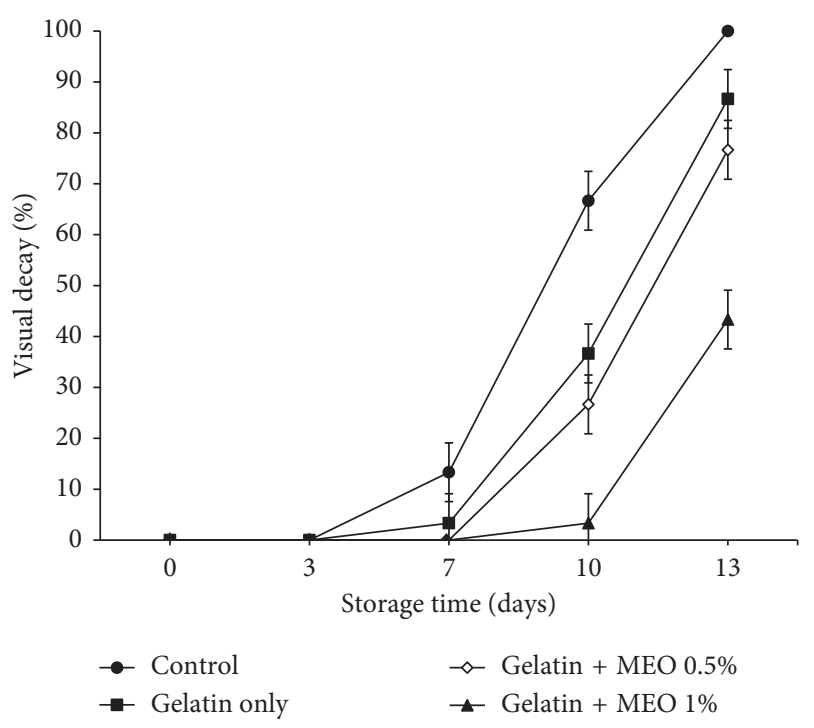

FIgURE 4: Visual decay of coated and uncoated strawberries during storage at $4^{\circ} \mathrm{C}$ for 13 days. Vertical bars represent the standard deviation $(n=3)$.

fruits from advanced atmospheric dehydration and consequently delayed their senescence.

Visual decay of uncoated (T1) and coated (T2, T3, and T4) strawberries during storage time at $4^{\circ} \mathrm{C}$ is shown in Figure 4. As it can be observed, gelatin + MEO (1\%) (T4) was the most effective treatment protecting at least $60 \%$ of strawberries from decay after 13 days of cold storage while gelatin alone (T2) was the lowest effective treatment. Our results are in accordance with those obtained by Li et al. [36] using a polysaccharide-based coating for strawberries preservation. The high protection level in visual decay for $\mathrm{T} 4$ treatment can be attributed to antimicrobial activity of $\mathrm{MEO}$, as previously demonstrated with microbes being the first responsible for strawberries decay.

\section{Conclusions}

This study shows the effectiveness of coating-based gelatin + MEO (1\%) for postharvest strawberries preservation up to 13 days by delaying microbial growth. Physicochemical and sensorial properties (weight loss, TA, TSS, firmness, color, and TPC) of coated strawberries were always better than those of the control. Gelatin coating alone was not as effective as gelatin incorporated with MEO. The use of this combination would be a good alternative to extend shelf life of strawberries and to limit the use of pesticides in postharvest treatments.

\section{Data Availability}

The data used to support the findings of this study are included within the article.

\section{Conflicts of Interest}

The authors declare that there are no conflicts of interest regarding the publication of this paper.

\section{Acknowledgments}

This study was supported by the CNRST (Project no. PPR/2015/10).

\section{References}

[1] MAPMDREF, Agriculture en Chiffres 2016, Ministère d'Agriculture et Pêche Maritime, Morocco, 2016.

[2] AMPFR, Note Festival Fruits Rouges 2017, Association Marocaine de Producteurs de Fruits Rouges au Maroc, Morocco, 2017.

[3] J. Cheel, C. Theoduloz, J. A. Rodríguez, P. D. S. Caligari, and G. Schmeda-Hirschmann, "Free radical scavenging activity and phenolic content in achenes and thalamus from Fragaria chiloensis ssp. chiloensis, $F$. vesca and $F . \times$ ananassa cv. Chandler," Food Chemistry, vol. 102, no. 1, pp. 36-44, 2007.

[4] M. L. B. Almeida, C. F. H. Moura, R. Innecco, A. dos Santos, and F. R. de Miranda, "Postharvest shelf-life and fruit quality of strawberry grown in different cropping systems," African Journal of Agricultural Research, vol. 10, no. 43, pp. 40534061, 2015.

[5] T. J. Avis, C. Martinez, and R. J. Tweddell, "Effect of chlorine atmospheres on the development of Rhizopus rot [Rhizopus stolonifer] and gray mold [Botrytis cinerea] on stored strawberry fruits," Canadian Journal of Plant Pathology, vol. 28, no. 4, pp. 526-532, 2006.

[6] R. K. Dhall, "Advances in edible coatings for fresh fruits and vegetables: a review," Critical Reviews in Food Science and Nutrition, vol. 53, no. 5, pp. 435-450, 2013.

[7] J. H. Han, Innovations in Food Packaging, Elsevier, Amsterdam, Netherlands, 2005.

[8] C. Bouchra, M. Achouri, L. M. Idrissi Hassani, and M. Hmamouchi, "Chemical composition and antifungal activity of essential oils of seven Moroccan Labiatae against Botrytis cinerea Pers: Fr.," Journal of Ethnopharmacology, vol. 89, no. 1, pp. 165-169, 2003.

[9] S. Mohammadi, H. Aroiee, M. H. Aminifard, and $\mathrm{V}$. Jahanbakhsh, "In vitro and in vivo antifungal activates of the essential oils of various plants against strawberry grey mould disease agent Botrytis cinerea," Archives of Phytopathology and Plant Protection, vol. 45, no. 20, pp. 2474-2484, 2012.

[10] A. Fennane, I. Nechad, J. Al Figuigui, F. Errachidi, T. El Kamli, and L. Elghadraoui, "Activity in vitro of the oils of Rosmarinus officinalis and Lavandula officinalis on the mycelial growth of three lettuce mushrooms," International Journal of Scientific and Engineering Research, vol. 7, no. 9, pp. 160-171, 2016.

[11] M. Oussalah, S. Caillet, S. Salmiéri, L. Saucier, and M. Lacroix, "Antimicrobial and antioxidant effects of milk protein-based film containing essential oils for the preservation of whole beef muscle," Journal of Agricultural and Food Chemistry, vol. 52, no. 18, pp. 5598-5605, 2004.

[12] M. A. Rojas-Graü, R. J. Avena-Bustillos, C. Olsen et al., "Effects of plant essential oils and oil compounds on mechanical, barrier and antimicrobial properties of alginateapple puree edible films," Journal of Food Engineering, vol. 81, no. 3, pp. 634-641, 2007.

[13] L. Sánchez-González, M. Cháfer, A. Chiralt, and C. GonzálezMartínez, "Physical properties of edible chitosan films containing bergamot essential oil and their inhibitory action on Penicillium italicum," Carbohydrate Polymers, vol. 82, no. 2, pp. 277-283, 2010. 
[14] A. P. D. A. M. Foganholi, J. F. S. Daniel, D. C. Santiago, J. R. Orives, J. P. Pereira, and T. D. J. Faria, "Composição química e atividade antifúngica do óleo essencial de poejo em diferentes estágios de desenvolvimento," Semina: Ciências Agrárias, vol. 36, no. 5, p. 3091, 2015.

[15] A. Ait-Ouazzou, S. Lorán, A. Arakrak et al., "Evaluation of the chemical composition and antimicrobial activity of Mentha pulegium, Juniperus phoenicea, and Cyperus longus essential oils from Morocco," Food Research International, vol. 45, no. 1, pp. 313-319, 2012.

[16] N. B. Gol, P. R. Patel, and T. V. R. Rao, "Improvement of quality and shelf-life of strawberries with edible coatings enriched with chitosan," Postharvest Biology and Technology, vol. 85, pp. 185-195, 2013.

[17] C. Pagliarulo, F. Sansone, S. Moccia et al., "Preservation of strawberries with an antifungal edible coating using peony extracts in Chitosan," Food and Bioprocess Technology, vol. 9, no. 11, pp. 1951-1960, 2016.

[18] M. Ramos, A. Valdés, A. Beltrán, and M. Garrigós, "Gelatinbased films and coatings for food packaging applications," Coatings, vol. 6, no. 4, p. 41, 2016.

[19] H.-J. Yang, J.-H. Lee, K.-Y. Lee, and K. Bin Song, “Application of gelatin film and coating prepared from dried alaska pollock by-product in quality maintanance of grape berries," Journal of Food Processing and Preservation, vol. 41, no. 6, article e13228, 2017.

[20] J. Gómez-Estaca, A. López de Lacey, M. C. Gómez-Guillén, M. E. López-Caballero, and P. Montero, "Antimicrobial activity of composite edible films based on fish gelatin and chitosan incorporated with clove essential oil," Journal of Aquatic Food Product Technology, vol. 18, no. 1-2, pp. 46-52, 2009.

[21] F. M. Fakhouri, A. C. A. Casari, M. Mariano et al., "Effect of a gelatin-based edible coating containing cellulose nanocrystals (CNC) on the quality and nutrient retention of fresh strawberries during storage," IOP Conference Series: Materials Science and Engineering, vol. 64, article 012024, 2014.

[22] J. M. Jay, M. J. Loessner, and D. A. Golden, Modern Food Microbiology, Springer, New York, NY, USA, 7th edition, 2005.

[23] C. Patricia and AOAC International, Official Methods of Analysis of AOAC International, AOAC International, Gaithersburg, MD, USA, 16th edition, 1997.

[24] T. Siriwoharn, R. E. Wrolstad, C. E. Finn, and C. B. Pereira, "Influence of cultivar, maturity, and sampling on Blackberry (Rubus L. Hybrids) anthocyanins, polyphenolics, and antioxidant properties," Journal of Agricultural and Food Chemistry, vol. 52, no. 26, pp. 8021-8030, 2004.

[25] Y. Shahbazi, "Application of carboxymethyl cellulose and chitosan coatings containing Mentha spicata essential oil in fresh strawberries," International Journal of Biological Macromolecules, vol. 112, pp. 264-272, 2018.

[26] V. S. Bierhals, M. Chiumarelli, and M. D. Hubinger, "Effect of cassava starch coating on quality and shelf life of fresh-cut pineapple (Ananas comosus L. Merril cv 'Pérola')," Journal of Food Science, vol. 76, no. 1, pp. E62-E72, 2011.

[27] S. Badr, Valorisation de Plantes Aromatiques et Médicinales du Maroc Valorisation de Plantes Aromatiques et Médicinales Par l'analyse Chimique et l'Étude de la Bioactivite de Leurs Huiles Essentielles, Éditions Universitaires Européennes, Saarbrücken, Germany, 2010.

[28] P. Raquel, A. Kwiatkowsk, E. Clemente, and Campos, "Postharvest conservation of organic strawberries coated with cassava starch and chitosan," Ceres, vol. 58, no. 5, 2015.
[29] Y.-J. Shin, H.-Y. Song, and K. B. Song, "Effect of a combined treatment of rice bran protein film packaging with aqueous chlorine dioxide washing and ultraviolet-C irradiation on the postharvest quality of 'Goha' strawberries," Journal of Food Engineering, vol. 113, no. 3, pp. 374-379, 2012.

[30] M. Petriccione, F. Mastrobuoni, M. Pasquariello et al., "Effect of chitosan coating on the postharvest quality and antioxidant enzyme system response of strawberry fruit during cold storage," Foods, vol. 4, no. 4, pp. 501-523, 2015.

[31] H. M. Díaz-Mula, M. Serrano, and D. Valero, "Alginate coatings preserve fruit quality and bioactive compounds during storage of sweet cherry fruit," Food and Bioprocess Technology, vol. 5, no. 8, pp. 2990-2997, 2012.

[32] S. H. A. Amal, M. M. El-Mogy, H. E. Aboul-Anean, and B. W. Alsanius, "Improving strawberry fruit storability by edible coating as a carrier of thymol or calcium chloride," Journal of Horticultural Science \& Ornamental Plants, vol. 2, no. 3, pp. 88-97, 2010.

[33] S. Y. Wang and H. Gao, "Effect of chitosan-based edible coating on antioxidants, antioxidant enzyme system, and postharvest fruit quality of strawberries (Fragaria x aranassa Duch.)," LWT-Food Science and Technology, vol. 52, no. 2, pp. 71-79, 2013.

[34] E. Poverenov, Y. Zaitsev, H. Arnon et al., "Effects of a composite chitosan-gelatin edible coating on postharvest quality and storability of red bell peppers," Postharvest Biology and Technology, vol. 96, pp. 106-109, 2014.

[35] A Hoda Khalil and M. Shimaa Hassan, "Ascorbic acid, $\beta$-carotene, total phenolic compound and microbiological quality of organic and conventional citrus and strawberry grown in Egypt," African Journal of Biotechnology, vol. 14, no. 4, pp. $272-277,2015$.

[36] L. Li, J. Sun, H. Gao et al., "Effects of polysaccharide-based edible coatings on quality and antioxidant enzyme system of strawberry during cold storage," International Journal of Polymer Science, vol. 2017, Article ID 9746174, 8 pages, 2017.

[37] M. J. Anttonen, K. I. Hoppula, R. Nestby, M. J. Verheul, and R. O. Karjalainen, "Influence of fertilization, mulch color, early forcing, fruit order, planting date, shading, growing environment, and genotype on the contents of selected phenolics in strawberry ( Fragaria $\times$ ananassa Duch.) fruits," Journal of Agricultural and Food Chemistry, vol. 54, no. 7, pp. 2614-2620, 2006.

[38] R. I. Ventura-Aguilar, S. Bautista-Baños, G. Flores-García, and L. Zavaleta-Avejar, "Impact of chitosan based edible coatings functionalized with natural compounds on Colletotrichum fragariae development and the quality of strawberries," Food Chemistry, vol. 262, pp. 142-149, 2018.

[39] G. Oms-Oliu, R. Soliva-Fortuny, and O. Martín-Belloso, "Edible coatings with antibrowning agents to maintain sensory quality and antioxidant properties of fresh-cut pears," Postharvest Biology and Technology, vol. 50, no. 1, pp. 87-94, 2008.

[40] P. Hernández-Muñoz, E. Almenar, V. D. Valle, D. Velez, and R. Gavara, "Effect of chitosan coating combined with postharvest calcium treatment on strawberry (Fragaria $\times$ ananassa) quality during refrigerated storage," Food Chemistry, vol. 110, no. 2, pp. 428-435, 2008.

[41] E. Velickova, E. Winkelhausen, S. Kuzmanova, V. D. Alves, and M. Moldão-Martins, "Impact of chitosan-beeswax edible coatings on the quality of fresh strawberries (Fragaria ananassa cv Camarosa) under commercial storage conditions," LWT-Food Science and Technology, vol. 52, no. 2, pp. 80-92, 2013. 


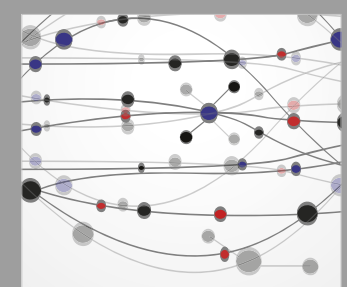

The Scientific World Journal
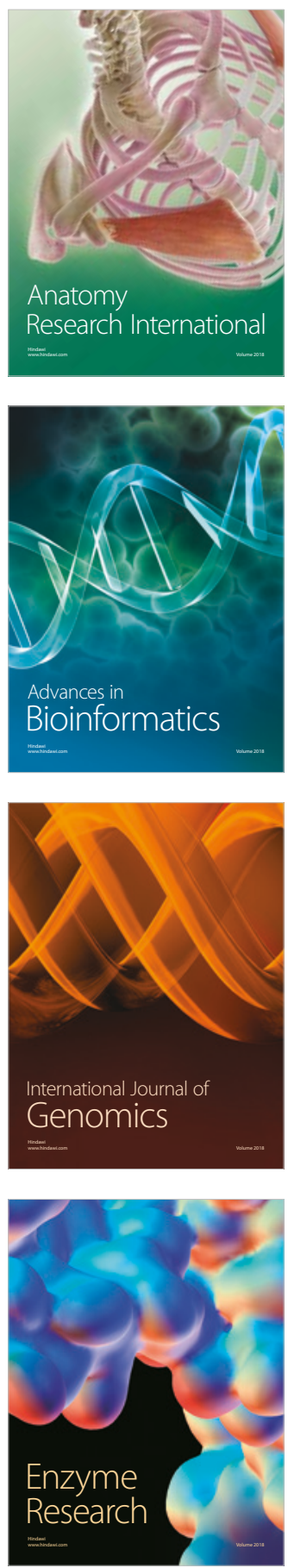
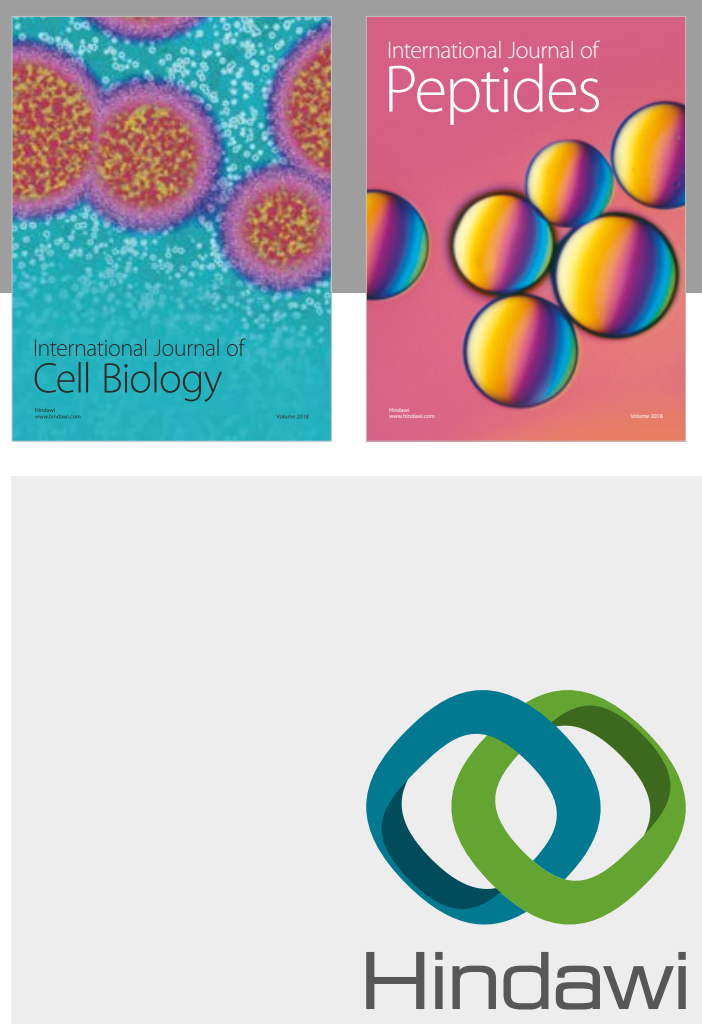

Submit your manuscripts at

www.hindawi.com
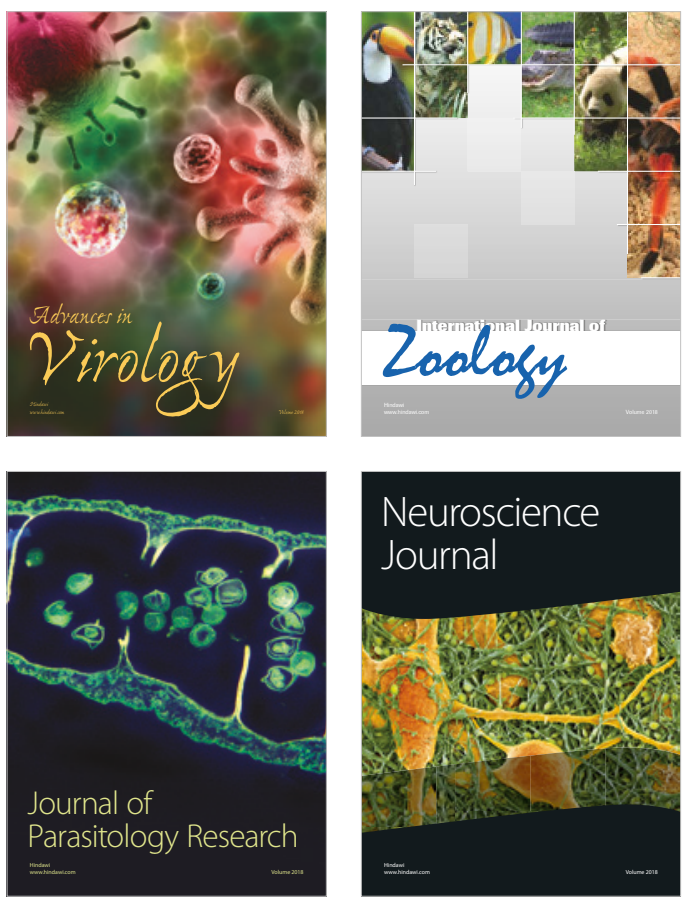
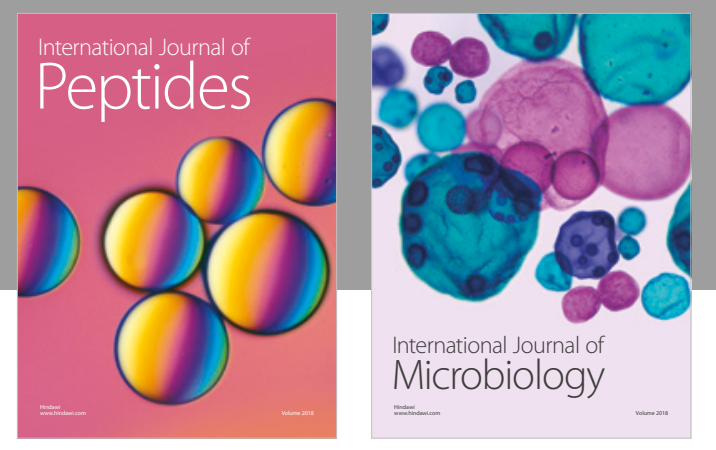

nternational Journal of Microbiology
Journal of
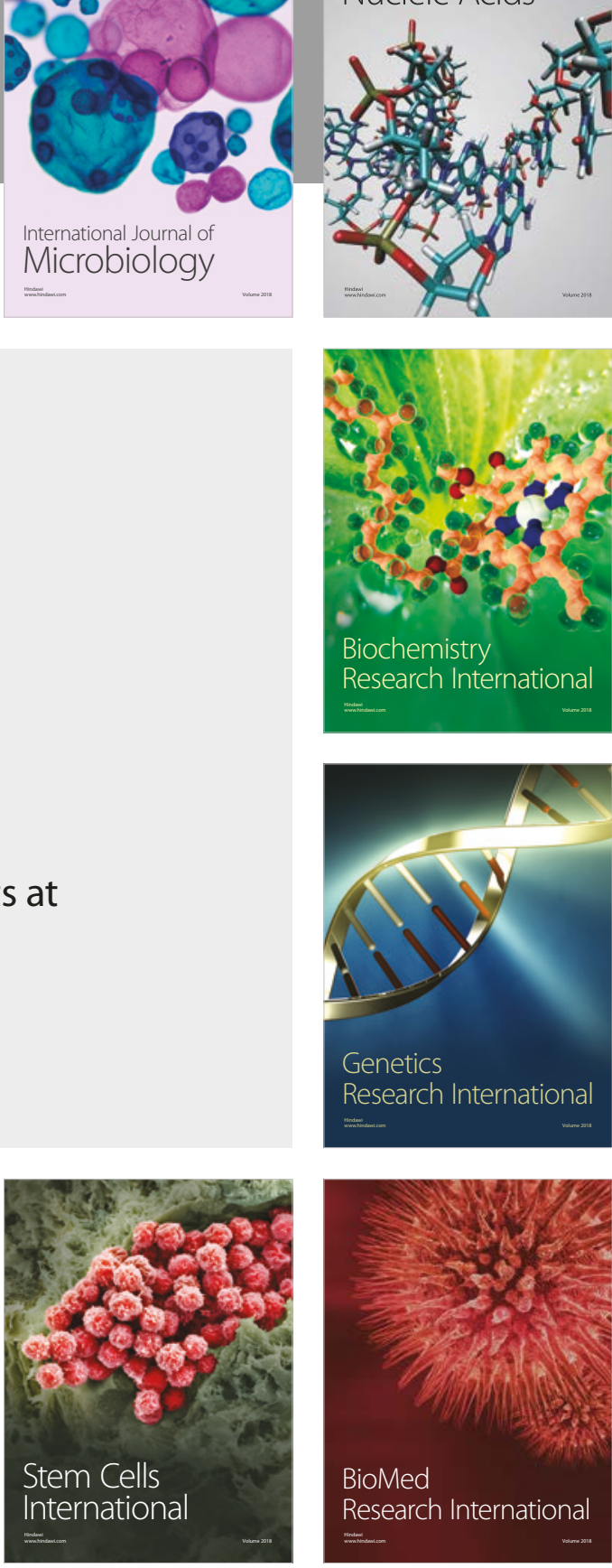
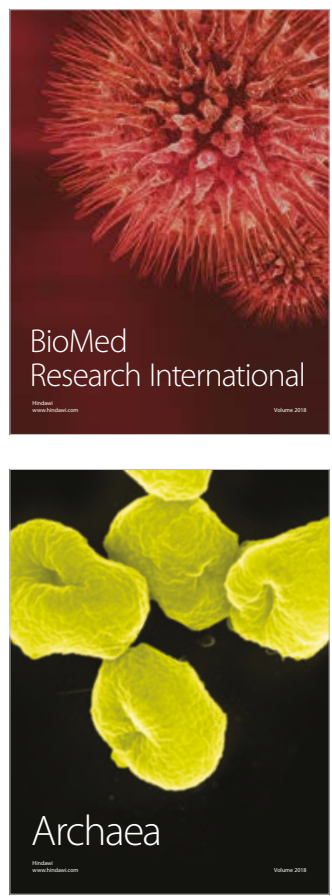